\title{
Environmental impacts integrated assessment of Usina Verde (COPPE/UFRJ)
}

The collection and disposal of solid waste is increasingly worrying public opinion and municipal administrations. Some measures have been carried out and shows good preliminary results. One such example is USINA VERDE, which receives 30 tons of solid waste daily. The waste is segregated according to the possibility of reuse or recycling and the rest is incinerated, generating energy and by-products. However, even presenting a set of environmental benefits, the facility needs to be the target of environmental impact assessments on a constant basis. The objective of this article is to evaluate the main expected impacts in the various phase of the project, namely those of implementation and operation of USINA VERDE, through matrix support and mathematical modeling of them. The proposed methodology shows that the facility is environmentally viable, provided that programs to mitigate its impacts are implemented.

Keywords: Environmental impact; Solid waste; Environmental impact assessment.

\section{Avaliação integrada de impactos ambientais da Usina Verde (COPPE/UFRJ)}

\begin{abstract}
A coleta e a destinação dos resíduos sólidos, preocupa de forma cada vez mais intensa, a opinião pública e as administrações municipais. Algumas medidas têm sido realizadas, e preliminarmente apresentam bons resultados, um destes empreendimento é a USINA VERDE, que recebe diariamente 30 toneladas de resíduos sólidos. Estes são separados em função da possibilidade de reutilização ou de reciclagem e o restante é incinerado, gerando energia e subprodutos. Contudo, mesmo apresentando um conjunto de benefícios ambientais, este empreendimento precisa ser alvo de avaliações de impactos ambientais de forma constante. $O$ objetivo deste artigo é avaliar os principais impactos esperados nas diversas fases do empreendimento, nomeadamente as de implantação e operação da USINA VERDE, através da matriciação e modelagem matemática dos mesmos. A metodologia proposta se prestou ao seu objetivo, demostrando de forma clara que o empreendimento estudo é viável do ponto de vista ambiental, desde que sejam implementados programas de mitigação dos seus impactos.
\end{abstract}

Palavras-chaves: Impacto ambiental; Resíduos sólidos; Avaliação de impactos ambientais.

Josimar Ribeiro de Almeida (iD

Universidade do Estado do Rio de Janeiro, Brasil http://lattes.cnpq.br/3215586187698472

http://orcid.org/0000-0001-5993-0665 almeida@poli.ufri.br

Cleber Vinicius Vitorio da Silva (i)

Universidade Federal Rural do Rio de Janeiro, Brasil http://lattes.cnpq.br/4275890458575782

http://orcid.org/0000-0001-8337-9615

heliumcorp@heliumcorp.com.br

Camilo Pinto de Souza (iD)

Universidade Federal Rural do Rio de Janeiro, Brasil http://lattes.cnpq.br/5526361137852985

http://orcid.org/0000-0002-5354-3194

capisouza@yahoo.com.br
Pauli Adriano de Almada Garcia Universidade Federal Fluminense, Brasil http://lattes.cnpq.br/3866888351512590 http://orcid.org/0000-0002-3934-4332 pauliadriano@id.uff.br

Gustavo Alveiro Lins (D)

Universidade do Estado do Rio de Janeiro, Brasi http://lattes.cnpq.br/5173989372426437

http://orcid.org/0000-0002-0244-6925 gustavoaveiro@gmail.com

Elenice Rachid da Silva Lenz (iD

Universidade do Estado do Rio de Janeiro, Brasi

http://lattes.cnpq.br/4557023865361858

http://orcid.org/0000-0002-1440-4271

erachid@pet.coppe.ufri.br
Laís Alencar de Aguiar (iD)

Comissão Nacional de Energia Nuclear, Brasi http://lattes.cnpq.br/5785500333245448 http://orcid.org/0000-0002-1551-4085 aguiar.lais@gmail.com

Vanessa da Silva Garcia (D)

Universidade Federal Fluminense, Brasil http://lattes.cnpq.br/2206038698250045 http://orcid.org/0000-0002-7841-8410 laguiar@ird.gov.br

\section{Referencing this:}

ALMEIDA, J. R.; SILVA, C. V. V.; SOUZA, C. P.; GARCIA, P. A. A.; LINS, G. A.; LENZ, E. R. S.; AGUIAR, L. A.; GARCIA, V. S.. Título: sub Environmental impacts integrated assessment of Usina Verde (COPPE/UFRJ) título. Revista Ibero Americana de Ciências Ambientais, v.11, n.7, p.690-702, 2020. DOI: http://doi.org/10.6008/CBPC2179-6858.2020.007.0053 


\section{INTRODUCTION}

The collection and disposal of urban waste incisively concern public opinion and administrations at the municipal, state and federal levels. The scenario worsens with the country's continued and persistent urbanization process and the consequent anthropization of terrestrial and aquatic ecosystems. In the 2019 demographic census of Brazil it was found that more than $90 \%$ of Brazilian houses have an exclusive use of one bathroom. One third (33.7\%) of them, however, do not have drainage from the sewerage system or from a septic tank, a percentage that has remained stable since 2016. However, the number is much higher in the North region (78.2\%) and in the Northeast region (55.4\%) and much lower in the Southeast region (11.4\%) (IBGE, 2019).

This environmental reality has several environmental consequences due to the concentration of decomposing organic material with gas emanation and deterioration of groundwater sheet; Social and public health services due to the distressing access of poor populations to these deposits; Economical due to the increased distance, therefore, the cost of transporting the garbage until the landfill sites are reached as well as the increasing complexity of the management of the deposit areas (ALMEIDA et al., 2012).

The sanitary landfill is the most used technology by the government for the final destination of solid waste, however sometimes this technology has shown incredible limitations to be the final recipient of solid waste, this is, when not totally ineffective and primitive like the Santa Rosa Waste Treatment Center (Santa Rosa CTR) located in Seropédica (RJ) this is the landfill that receives all waste from the metropolitan region of Rio de Janeiro and the city of Seropédica. CTR Santa Rosa is located on the Piranema Aquifer which is one of the three most important drinking water reservoirs in the state of Rio de Janeiro (MARQUES et al., 2008). Its renewable reserves estimated at $1.6 \mathrm{~m}^{3} / \mathrm{s}$, sufficient to supply 140,000 families.

The region where the aquifer is located is sandy and has one of the most threatened killifish species in Brazil the Notholebias minimus, in addition to the fact that the landfill is also in the area of influence of one of the most threatened amphibian species in the american continent the Physalaemus soaresi (SILVA et al., 2011). Another fact of technological questionability is the fact that this CTR has constant leaks from the slurry ponds and according to the studies by SILVA et al. (2013) the surface waters surrounding the CTR Santa Rosa are contaminated by several heavy metals, among which the most prominent is uranium (U). These waters are subsequently collected by the Guandu Water Treatment Station (ETA Guandu) and distributed for consumption by the 9 million inhabitants of the metropolis in Rio de Janeiro (SILVA et al., 2013).

The installation of a project will always generate negative environmental impacts on terrestrial and aquatic ecosystems, however the extent of this impact will depend on the technologies used in addition to applied environmental management, In the case of conventional landfills the extent of the impact will always cover orders of colossal magnitudes, since in most cases the synergy of the ecosystems in which they are implanted is not taken into account, nor is their homeostasis, much less taken into account plume of extension of this impact. Environmental Impact is any change in the physical, chemical and biological properties of the environment, caused by any form of matter or energy resulting from human activities, that 
directly or indirectly affect: the health, safety and well-being of the population; social and economic activities; the biota; the aesthetic and sanitary conditions of the environment; the quality of environmental resources; biological indexes and ecological attributes (ALMEIDA et al., 2005).

The assessment of an environmental impact, allows the creation of strategies that enable the prophylaxis and mitigation of this impact, that is, the determination of the multifactoriality of the actors involved in the impact extension (SILVA et al., 2013).

Environmental impact assessment procedures are employed in at least 181 countries (Morgan, 2012) and changes in laws and regulations regarding public decision-making processes, based on AIA, have also occurred in countries like Canada (GIBSON, 2012), Colombia (TORO et al., 2010), Australia, United Kingdom and South Africa (BOND et al., 2014).

The issue of solid waste in the contemporary world is undoubtedly one of the most important socioenvironmental discussion demands on Earth, even if we find ourselves in the 21st century, there is still a considerable percentage of human beings without access to selective collection. In Brazil, this reality is chaotic (SILVA et al., 2011).

The systematization of a methodology based on the matrix of impacts, makes it possible to access the magnitude of this impact on the environment and society, as well as to measure the environmental damage caused during the implementation and operation phase of a project, being observed for each scenario the best impact mitigation measure (ALMEIDA et al., 2008).

Faced with this scenario the COPPETEC Foundation of UFRJ in partnership with USINA VERDE, built the USINA VERDE Technological Center project, which has been in operation since 2004, the plant which is located on Ilha do Fundão, close to the University Hospital, receives 30 daily tons of solid waste, already pretreated from the Comlurb landfill in the Caju neighborhood.

At the unit waste that can be reused or recycled is removed the rest is incinerated. The acid gases resulting from the incineration of the waste are washed with alkaline water where the final results are mineralization and water. In addition to being environmentally friendly the solid waste plant also has an economical aspect since about $90 \%$ of the weight of the waste is transformed into energy. Thanks to a heat recovery boiler installed in the project oven the heat from the combustion gas incineration is used to generate electricity enough to supply 2300 homes with an average consumption of $200 \mathrm{~kW} / \mathrm{month}$.

The objective of this scientific work was to evaluate the main impacts expected in the various phases of the undertaking namely those of implementation and operation of USINA VERDE through their impact assessment matrice and mathematical modeling. In order to facilitate the analysis of impacts these were grouped according to the changes and interferences. These according to the categories: changes in the physical environment of the area of influence; changes in the biotic environment of the area of influence; changes in the socio-economic and cultural environment of the area of influence. It is expected that the results evidenced in this article may be a driving force for the generation of new technologies in opposition to the current and primitive model for the disposal of solid waste as well as an evaluation mark of the enterprises that are destined to receive them. 


\section{MATERIALS AND METHODS}

\section{Mathematical Modeling Used to Estimate Environmental Impacts}

The construction of an algorithm admits two basic factors sufficient to measure and compare environmental impacts (ALMEIDA et al., 2008) resulting from the manifestation of phenomena: the first referred to the force or intensity of the impact occurrence (Vpi) and the second referred to the importance or relevance of the impact $(\mathrm{Rg})$ in the spatio-temporal context of its occurrences. It means to say that for an impact to be estimated it is necessary that the environmental phenomenon with which it is associated ( $i$ ) manifests itself or has a reasonable tendency to manifest, (ii) has the capacity to induce environmental transformation and ( $\mathrm{iii}$ ) affects a given area, through an environmental factor or variable (IA), during a given time interval. Admitting that the phenomenon (generic) fen' answer the first condition it remains to know the two factors that express its impact. They are: the Vpi that represents the potential value of the impact of fen', that is, its potential intensity since there is still no certainty that it is or will occur; the Rg which represents its global relevance in the space-time contex.

The impact associated with fen ${ }^{i}$ here will be called fen ${ }^{i}$ distributed environmental impact and pointed through the expression lad $\left\{\mathrm{fen}^{\mathrm{i}}\right\}=\mathrm{Vpi}$. Rg.

Estimates of the impact of a phenomenon need to have a time horizon since the availability and consistency of the data used are limited (Almeida et al., 2008). was named for managerial time the time span that impact estimates are able to cover. Therefore, all works carried out using this model need to explain the time horizon of their prognosis. Let $\left\{\mathrm{la}^{\mathrm{n}}\right\}$ be the set of $\mathrm{n}$ indicators that explain fen'.

Any $\mathrm{Al}$ belongs to the range $\left[I_{\min } ; L^{\max }\right]$ where $I_{\min }$ and $L^{\max }$ the minimum and maximum limits of interest of the considered indicator are constituted $\mathrm{IA}^{\mathrm{i}}$.

Let $l a^{k}$ be any element of $\left\{I^{n}\right\}$. Indicating $\left\{D^{k}{ }_{t 1}, D^{k}{ }_{t 2}, \ldots, D^{k}{ }_{t m}\right\}$ the set of values assumed by $I A^{k}$ im $m$ measurements made in the interval $\left[t_{1} ; t_{m}\right]$ the set $\left\{D^{k}{ }_{t m}\right\}$, in that time interval thus constituting a basic element for the diagnosis of the environmental factor to which $\mathbf{I A}^{\mathbf{k}}$ is linked. Be $\left\{D^{k}{ }_{\text {tm }}\right\}$ without the presence of the enterprise. Generalized this approach for all $\left\{\mathrm{Ia}^{\mathrm{n}}\right\}$ is expressed:

$$
\begin{aligned}
& I^{1}=D^{1} t 1, D^{1} t 2, \ldots, D^{1} t m, D^{1} t m+z \\
& I A^{2}=D^{2} t 1, D^{2} t 2, \ldots, D^{2} t m, D^{2} t m+z \\
& I^{k}=D^{k} t 1, D^{k} t 2, \ldots, D^{k} t m, D^{k} t m+z \\
& I^{n}=D^{n} t 1, D^{n} t 2, \ldots, D^{n} t m, D^{n} t m+z
\end{aligned}
$$

This matrix of indicators explains the fen' behavior for all $t$ belonging to the interval $\left[t_{1} ; t_{m+z}\right]$. Each column represents the scenario of the fen ${ }^{i}$ behavior at a given time according to the explanatory capacity of the selected indicators. Each $D^{i}{ }_{t i}$ cell of the fen ${ }^{i}$ environmental indicator matrix corresponds to an estimated value for the environmental quality resulting from it. In this way each phenomenon considered be it occurring virtual or predicted is associated with a matrix of indicators. And each matrix of indicators is linked to an environmental quality matrix derived from the manifestations of the phenomenon. 
Let $Q a^{k}{ }_{t m}$ be the environmental quality derived from the virtual presence of fen in time $t_{m}$ in function of the measured behavior of $I A^{k}$ in the same instant of time.

Let $Q a^{k}{ }_{t m}$ is the predicted environmental quality from $\left[Q a^{k}{ }_{t m+z}\right]$ for the time $Q a^{k}{ }_{t m+z}$ without the presence of the enterprise to be implemented.

Any $Q a^{n} t \in[0 ; 1]$ which are the extreme values referring to the maximum and minimum limits of interest of $I A^{n}$.

Generalizing this approach to all $\left\{\mathrm{Ia}^{\mathrm{n}} \mathrm{tm}\right\}$ is expressed:

$$
\begin{aligned}
& \mathrm{QA}\left(\mid \mathrm{A}^{1}\right)=\left\{\mathrm{QA}^{1}{ }_{\mathrm{t} 1}, \mathrm{QA}^{1} \mathrm{t} 2, \ldots, \mathrm{QA}^{1}{ }_{\mathrm{tm}}, \ldots, \mathrm{QA}^{1}{ }_{\mathrm{tm}+\mathrm{z}}\right\} \\
& Q A\left(I A^{2}\right)=\left\{Q A^{2}{ }_{t 1}, Q A^{2} t 2, \ldots, Q A^{2}{ }_{t m}, \ldots, Q A^{2}{ }_{t m+2}\right\}
\end{aligned}
$$

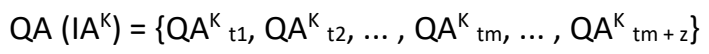

$$
\begin{aligned}
& Q A\left(I A^{n}\right)=\left\{Q A^{n}{ }_{t 1}, Q A^{n} t 2, \ldots, Q A^{n} t m, \ldots, Q A^{n} t m+2\right\}
\end{aligned}
$$

The environmental quality matrix expresses the results of the functional and behavioral variations of the environmental factors affected by fen in the interval $\left[t 1 ; t_{m+z}\right]$. Each column represents the study's trend scenario addressing the virtual presence of fen ${ }^{i}$. The potential value of the impact of this event on the trend scenario predicted for a $t_{w}$ time is given by Vpi $\left\{f_{e n}{ }_{t w}\right\}=\left[\left(Q A^{1}{ }_{t w}{ }^{1}\right)+\ldots+\left(Q a^{n}{ }^{1} t w\right)\right] / n$, so, $V p i\left\{f e n^{i}{ }_{t w}\right\}=\Sigma\left[\left(Q A^{1}\right.\right.$ $\left.\left.\mathrm{tw}^{1}\right)+\ldots+\left(\mathrm{Qa}{ }^{\mathrm{n}}{ }_{\mathrm{tw}}\right)\right] / \mathrm{n}$.

In this way Vpi $\left\{\mathrm{fen}_{\mathrm{tw}}{ }_{\mathrm{tw}}\right\}$ is estimated through the average of the deviations calculated between the environmental quality derived from the performance of each indicator that explains fen ${ }^{i}$ w and the environmental quality associated with the best performance of those same indicators which by definition, has a value equal to 1 (one).

By analogy for the prognosis of the succession scenario, the estimate of the potential value of the impact of fen ${ }^{i}$ w undergoes the same treatment performed the two matrices presented.

Therefore, let $Q A E^{n}{ }_{t m+z}$ be the environmental quality predicted from $Q A^{n}{ }_{t m+z}$ with the presence of the enterprise to be implemented. Then, the potential value of the impact of fen ${ }^{i}$ w will be given by Vpi $\left\{f^{i}{ }^{i}{ }^{\prime}\right\}=\Sigma\left[\left(Q A E^{n}{ }_{t w}-1\right)\right] / n$.

Therefore, the assessment of the impact of fen ${ }^{i}{ }_{\mathrm{w}}$, based on the alternatives explained by the trend and succession scenarios is given by $V p i\left\{f^{1}{ }^{i}{ }_{t w}\right\}=\Sigma\left[\left(Q A E^{n}{ }_{t w}-1\right)\right] / n$, so, $V p i\left\{f^{\prime}{ }^{i}{ }_{t w}\right\}=\Sigma\left[\left(Q a^{n}{ }_{t w}-1\right)\right] / n$. So, we have the expression:

$$
\text { Vpi }\left\{f_{e n}{ }^{i}{ }_{t w}=\Sigma\left[\left(Q A E^{n}{ }_{t w}-Q a^{n}{ }_{t w}\right)\right] / n\right.
$$

Global relevance is an expression of the spatio-temporal importance of the phenomenon. The duration of the occurrence of fen is estimated from the knowledge developed by the described and analytical diagnoses of the study. Its valuation is obtained through the relationship between the time predicted for the manifestations of a phenomenon and the managerial time adopted by the study. Thus, $d \in(0 ; 1]$ given that if $d=0$ then there will be no predicted manifestations of the event during the interval determined by the managerial time.

The lack behaves inversely in relation to the duration, i.e., given any phenomenon the greater its lack the lower its global relevance provided that the other attributes remain constant. Its valuation is given by the 
relationship between the estimated time for the beginning of event manifestations and the managerial time adopted. Thus, $c \in[0 ; 1)$, in case of, if $c=1$ there will be no manifestation of the event within the established managerial time interval.

Finally, the distribution of fen is explained by the relationship between the amount of the factor directly affected or affectable and the HSI value (Habitat Suitability Index) of that same factor in the study area (Almeida et al., 2008). The range of variation of the distribution estimated like the other attributes is $(0 ; 1]$, since if $b=0$ then there is no phenomenon.

Considering the range of variation of each of the attributes used it appears that the domain of $\mathrm{Rg}$ $\left\{\mathrm{fen}^{\mathrm{i}}\right\}=(0 ; 1)$ without any of the three attributes having different representativeness in explaining the global relevance of fen'. The expression of global relevance is given by $\operatorname{Rg}\left\{f^{\prime} n^{\prime}\right\}=d . b .(1-c)$. Finally, the estimate of the distributed environmental impact of fen ${ }^{i}{ }_{t w}$ It is given by lad $\left\{f e n^{i}{ }_{t w}\right\}=d \cdot b \cdot(1-c) \cdot \Sigma\left[\left(Q A E^{n}{ }_{t w}-Q A^{n}{ }_{t w}\right)\right] / n$.

The use of only one environmental indicator per phenomenon in the vast majority of cases is sufficient to express the variation in environmental quality provided by its manifestations. Therefore, the expression of the impact takes the following form, lad $\left\{\mathrm{fen}^{\mathrm{i}}{ }_{\mathrm{tw}}\right\}=d \cdot b \cdot(1-c) \cdot\left(\mathrm{QAE} \mathrm{tw}_{\mathrm{tw}}-\mathrm{Qa}_{\mathrm{tw}}\right)$.

Based on these conditions an integrated evaluation system is used. The proposition is based on two aspects: assessment of the area's environmental capacity to absorb the potential effects of the enterprise to be installed; assessment of environmental impacts generated from the identification and qualification of industrial activities.

\section{Qualitative Assessment of Environmental Impacts}

The evaluation methodology started from the definition of environmental impact contained in CONAMA Resolution no 001/86 which considers as such any change in the physical, chemical and biological properties of the environment caused by any form of matter or energy resulting from the undertaking activities under study that directly or indirectly affect: the health, safety and well-being of the population; social and economic activities; the biota; the aesthetic and sanitary conditions of the environment and the quality of environmental resources.

Once the definition of environmental impact is accepted, it was identified and qualified, based on its attributes listed in the CONAMA Resolution no 001/86 (Table 1).

The definition of the quantitative spectrum is of supreme importance, because through it the variables of the expression. $\mathrm{Rg}=\mathrm{d} \cdot \mathrm{b} .(1-\mathrm{c})$ will be valued where its subsequent modeling will allow to evaluate the enterprise as: not feasible, feasible without environmental plans and feasible with environmental plans.

Table 1: Attributes considered by CONAMA Resolution $\mathrm{n}$ 0 001/86.

\begin{tabular}{|c|l|}
\hline Attribute & \multicolumn{1}{c|}{ Qualitative spectrum } \\
\hline Qualification & Positive or beneficial: when the action results in improving the quality of an environmental factor or parameter. \\
\cline { 2 - 2 } & Negative or adverse: when the action results in damage to the quality of an environmental factor or parameter. \\
\hline \multirow{2}{*}{ Causality } & Direct: resulting from a simple cause and effect relationship. \\
\cline { 2 - 2 } & Indirect: resulting from a secondary reaction to the action or when it is part of a chain of reaction. \\
\hline \multirow{2}{*}{$\begin{array}{c}\text { Geographic } \\
\text { Coverage }\end{array}$} & Local: the action affects only the locus itself and its surroundings. \\
\cline { 2 - 2 } & Regional: the impact is felt beyond the vicinity of the place where the action takes place. \\
\cline { 2 - 2 } & Strategic: the affected environmental component is of collective or national importance. \\
\hline
\end{tabular}




\begin{tabular}{|c|l|}
\hline \multirow{2}{*}{ Lack } & Immediate: when the effect appears the instant the action occurs. \\
\cline { 2 - 3 } Duration & Medium or long term: when the impact manifests itself at a certain time after the action; \\
\hline \multirow{2}{*}{ Periodicity } & $\begin{array}{l}\text { Permanent: when, once the action has been carried out the effects do not cease to manifest within a known } \\
\text { time horizon. }\end{array}$ \\
\cline { 2 - 3 } & Temporary: when effects have a limited duration. \\
\cline { 2 - 3 } & Cyclic: when the effect manifests itself at certain time intervals. \\
\cline { 2 - 3 } & Flashing: when the effect manifests itself at random intervals of time. \\
\hline Reversibility & $\begin{array}{l}\text { Reversible: when the affected environmental factor or parameter, once the action ceases, returns to its original } \\
\text { conditions. }\end{array}$ \\
\cline { 2 - 3 } & $\begin{array}{l}\text { Irreversible: when the action has taken place the affected environmental factor or parameter does not return } \\
\text { to its original conditions in a foreseeable case. }\end{array}$ \\
\hline
\end{tabular}

Source: CONAMA Resolution no 001/86.

Table 2: Attributes and respective interval scale.

\begin{tabular}{|c|c|c|c|}
\hline Attribute & Qualitative spectrum & Quantitative Spectrum & Variable \\
\hline \multirow{2}{*}{ Qualification } & Positive & - \\
\cline { 2 - 3 } & Negative & a \\
\hline \multirow{2}{*}{ Causality } & Indirect & $\{0 ; \ldots ; 0.4\}$ \\
\cline { 2 - 4 } & Direct & $\{0.5 ; \ldots ; 1\}$ \\
\hline \multirow{3}{*}{ Geographic Coverage } & Local & $\{0 ; \ldots ; 0.3\}$ \\
\cline { 2 - 4 } & Regional & $\{0.4 ; \ldots ; 0.6\}$ \\
\cline { 2 - 4 } & Estrategic & $\{0.7 ; \ldots ; 1\}$ \\
\cline { 2 - 4 } & Long Term & $\{0 ; \ldots ; 0.3\}$ \\
\cline { 2 - 4 } & Medium Term & $\{0.7 ; \ldots ; 1\}$ \\
\hline \multirow{2}{*}{ Lack } & Immediate & $\{0 ; \ldots ; 0.4\}$ \\
\hline \multirow{2}{*}{ Periodicity } & Temporary & $\{0.5 ; \ldots ; 1\}$ \\
\hline \multirow{2}{*}{ Reversebility } & Permanent & $\{0 ; \ldots ; 0.3\}$ \\
\cline { 2 - 4 } & Cyclic & $\{0.4 ; \ldots ; 0.6\}$ \\
\hline
\end{tabular}

Source: Almeida et al. (2008).

The main impacts expected in the various phases of the project are listed below, that is, the implementation phase and the operation phase of USINA VERDE. In order to facilitate the analysis of the Report the impacts were grouped according to the changes and interferences. Thus, the impacts were grouped according to the categories: changes in the physical environment of the area of influence; changes in the biotic environment of the area of influence; changes in the socio-economic and cultural environment of the area of influence. The omission of any item in the categories previously listed implies the absence of relevant impacts pertaining to these items.

During the implementation phase, the methodology with a focus on possible impacts on the physical, biotic and social environment of the area of direct influence and directly affected by the project must be followed in such a way as to model all negative impacts that will occur. The indicators are an immediate reflection of the presence or absence of the impact and the valuation of the impact to its extent, scale and periodicity in time and space (table 3).

Table 3: Descriptive analysis of impacts in the implementation phase.

\begin{tabular}{|c|c|c|c|}
\hline Impact & Events & Indicators & Qualitative Valuation \\
\hline Noise pollution & $\begin{array}{c}\text { Like any project the construction of USINA VERDE } \\
\text { will bring an increase in the level of noise due to } \\
\text { the presence of machines and trucks }\end{array}$ & $\begin{array}{c}\text { Average noise level (in } \\
\text { decibels) near works }\end{array}$ & $\begin{array}{c}\text { Negative, direct, local, } \\
\text { immediate, } \\
\text { temporary, cyclical } \\
\text { and reversible }\end{array}$ \\
\hline Atmospheric pollution & Like any work the construction of USINA VERDE will & Number of particles in & Negative, direct, local, \\
\hline
\end{tabular}




\begin{tabular}{|c|c|c|c|}
\hline & $\begin{array}{l}\text { bring with it an increase in the amount of particulates } \\
\text { in the atmosphere }\end{array}$ & suspension in the Air Basin & $\begin{array}{l}\text { immediate, } \\
\text { temporary, } \\
\text { intermittent and } \\
\text { reversible }\end{array}$ \\
\hline Temporary job creation & $\begin{array}{l}\text { The construction of USINA VERDE will employ a } \\
\text { certain amount of skilled or unskilled labor. With the } \\
\text { works trade is also maximized close to construction, } \\
\text { especially with regard to meeting the basic needs of } \\
\text { workers }\end{array}$ & Number of jobs & $\begin{array}{l}\text { Positive, direct, } \\
\text { regional, medium } \\
\text { term, temporary, } \\
\text { constant, reversible }\end{array}$ \\
\hline Neighborhood effect & $\begin{array}{l}\text { USINA VERDE as well as other projects for the final } \\
\text { destination of solid waste imply a series of ecotonal } \\
\text { effects on the conservation fragments. The change in } \\
\text { the surrounding physiography, small changes in } \\
\text { energy and water balances cause these effects }\end{array}$ & $\begin{array}{l}\text { Alteration of the average } \\
\text { phytophysiognomy of } \\
\text { restinga and mangrove } \\
\text { fragments }\end{array}$ & $\begin{array}{l}\text { Negative, direct, } \\
\text { regional, immediate, } \\
\text { temporary, } \\
\text { intermittent and } \\
\text { reversible }\end{array}$ \\
\hline $\begin{array}{l}\text { Disturbance and loss of } \\
\text { biodiversity in the } \\
\text { surrounding ecosystems }\end{array}$ & $\begin{array}{c}\text { The set of works causes disturbances, such as those } \\
\text { of the neighborhood effect. Biodiversity loss will } \\
\text { occur at the genetic variance level }\end{array}$ & $\begin{array}{l}\text { Loss of native biodiversity } \\
\text { and increase in synanthropic } \\
\text { species }\end{array}$ & $\begin{array}{l}\text { Negative, direct, local, } \\
\text { immediate, } \\
\text { temporary, } \\
\text { intermittent and } \\
\text { reversible }\end{array}$ \\
\hline $\begin{array}{l}\text { Interference in traffic and } \\
\text { daily life of social groups }\end{array}$ & $\begin{array}{l}\text { During the period of implementation of the works a } \\
\text { series of interferences in the traffic of vehicles } \\
\text { inevitably occurs. Occasional obstructions will cause } \\
\text { an increase in traffic slowness at some points. Such a } \\
\text { situation is reflected in the daily life of social groups }\end{array}$ & Road traffic retention time & $\begin{array}{l}\text { Negative, direct, local, } \\
\text { immediate, } \\
\text { temporary, cyclical } \\
\text { and reversible }\end{array}$ \\
\hline
\end{tabular}

During the operation phase there are also a series of impacts described in Table 4 the extent of which reaches the environmental compartments and the social environment with positive and negative valuations depending on the impact.

Table 4: Descriptive Analysis of Impacts in the Operation Phase.

\begin{tabular}{|c|c|c|c|}
\hline Impact & Events & Indicators & $\begin{array}{l}\text { Qualitative } \\
\text { Valuation }\end{array}$ \\
\hline Noise pollution & $\begin{array}{l}\text { With the operation of machines, equipment, trucks, } \\
\text { etc., inherent to a plant for the final disposal of } \\
\text { solid urban waste, there will be an increase in the } \\
\text { local and regional noise level. The scope of this } \\
\text { impact will be represented by the internal area of } \\
\text { USINA VERDE and less intensely in the vicinity of } \\
\text { this }\end{array}$ & $\begin{array}{l}\text { Noise level (in decibels) near } \\
\text { USINA VERDE }\end{array}$ & $\begin{array}{l}\text { Negative, direct, } \\
\text { local, immediate, } \\
\text { permanent, } \\
\text { constant, reversible }\end{array}$ \\
\hline Generation of odors & $\begin{array}{l}\text { The supply of urban waste at USINA VERDE will } \\
\text { generate strong odors. The inconveniences caused } \\
\text { to the surrounding population and the operators. } \\
\text { The scope of this impact is directly related to the } \\
\text { emission rate promoted by the source and the } \\
\text { reach radius of the impact in unfavorable } \\
\text { conditions of wind and temperature, is at least } \\
1,000 \mathrm{~m}\end{array}$ & Odors & $\begin{array}{l}\text { Negative, direct, } \\
\text { local, immediate, } \\
\text { permanent, } \\
\text { intermittent and } \\
\text { reversible }\end{array}$ \\
\hline $\begin{array}{l}\text { Reduction of vector } \\
\text { proliferation }\end{array}$ & $\begin{array}{l}\text { The reduction of waste exposure points in the } \\
\text { University City will provide a reduction in the } \\
\text { proliferation of vectors }\end{array}$ & $\begin{array}{l}\text { Diversity of biovectors and } \\
\text { population density }\end{array}$ & $\begin{array}{l}\text { Positive, direct, } \\
\text { regional, } \\
\text { immediate, } \\
\text { permanent, } \\
\text { constant and } \\
\text { reversible }\end{array}$ \\
\hline $\begin{array}{l}\text { Reduction in the level of } \\
\text { contamination of soil and } \\
\text { aquifers }\end{array}$ & $\begin{array}{c}\text { The decrease in outbreaks and the time of } \\
\text { exposure to urban waste will reduce the level of } \\
\text { leachate production and consequently the level of } \\
\text { contamination of local soils and aquifers }\end{array}$ & $\begin{array}{l}\text { input and volume of xenobiotic } \\
\text { compounds in water bodies and } \\
\text { soil }\end{array}$ & $\begin{array}{l}\text { Positive, direct, } \\
\text { local, medium term, } \\
\text { permanent, } \\
\text { constant and } \\
\text { reversible }\end{array}$ \\
\hline Increase in vehicle traffic & $\begin{array}{c}\text { With the implantation of USINA VERDE and the } \\
\text { transportation of garbage by trucks this should } \\
\text { cause an increase in local traffic }\end{array}$ & average traffic speed & $\begin{array}{l}\text { Negative, direct, } \\
\text { local, immediate, } \\
\text { permanent, cyclical } \\
\text { and reversible } \\
\end{array}$ \\
\hline Job creation & $\begin{array}{l}\text { The operation of USINA VERDE will imply the offer } \\
\text { of employment for specialized and unskilled labor. } \\
\text { The area covered by this impact involves not only } \\
\text { the areas adjacent to the project, but also those } \\
\text { located in the regions closest to it }\end{array}$ & Abundance of jobs & $\begin{array}{l}\text { Positive, direct, } \\
\text { regional, medium } \\
\text { term, permanent, } \\
\text { constant and } \\
\text { reversible }\end{array}$ \\
\hline $\begin{array}{l}\text { Recycling and } \\
\text { mineralization of solid } \\
\text { waste }\end{array}$ & $\begin{array}{l}\text { Elimination / reduction to solid waste disposed of in } \\
\text { dumps }\end{array}$ & $\begin{array}{l}\text { Reduction of soil contamination, } \\
\text { groundwater and water courses, } \\
\text { elimination / reduction of vector } \\
\text { proliferation, availability of sterile }\end{array}$ & $\begin{array}{l}\text { positive, direct, } \\
\text { regional, long term, } \\
\text { permanent, } \\
\text { constant and }\end{array}$ \\
\hline
\end{tabular}




\begin{tabular}{|c|c|c|c|}
\hline & & $\begin{array}{l}\text { final product and consisting of } \\
\text { nutrient salts }\end{array}$ & reversible \\
\hline $\begin{array}{l}\text { Temporary impediment to } \\
\text { the operation of the } \\
\text { mineralization plant }\end{array}$ & $\begin{array}{l}\text { Use of small area destined to receive eventual inert } \\
\text { materials and attend emergency situations }\end{array}$ & $\begin{array}{l}\text { Disruption of the mineralization } \\
\text { plant beyond expected and } \\
\text { desired }\end{array}$ & $\begin{array}{l}\text { Negative, direct, } \\
\text { local, immediate, } \\
\text { permanent, cyclical } \\
\text { and reversible }\end{array}$ \\
\hline Change in air quality & $\begin{array}{l}\text { Atmospheric pollution, in case they are not met } \\
\text { current environmental rules, current environmental } \\
\text { guidelines and standards }\end{array}$ & $\begin{array}{l}\text { Emissions produced by the } \\
\text { burning and mineralization } \\
\text { process }\end{array}$ & $\begin{array}{l}\text { Negative, direct, } \\
\text { local, immediate, } \\
\text { permanent, } \\
\text { constant and } \\
\text { reversible }\end{array}$ \\
\hline
\end{tabular}

\section{RESULTS AND DISCUSSION}

It was possible to access algorithms to measure and compare environmental impacts during the deployment and operation phase of USINA VERDE.

The matrices show a summary of the environmental impacts with two matrices being generated, one for implementation phase of the enterprise and another for the operation phase. In both cases the impacts and alternatives to these were taken into account, correlating with the algorithms. And another matrix correlating the impacts, their alternatives and the attributes described in Table 1.

\section{Implementation Phase of the Solid Waste Plant}

The matrices are ordered according to the physical, biotic and socioeconomic means. The matrix of environmental impact algorithms $\left\{\mathrm{la}^{\mathrm{n}}\right\}$ with factors resulting from the phenomenon manifestation contains columns of impact intensity (Vpi) that measures the intensity of impact; the importance of impact (Rg) that measures its relevance the estimate of distributed impacts (EDI) with the respective nominal scale values (positive/negative).

For modeling the importance and relevance of the impact, that is, $\mathrm{Rg}=\mathrm{d} . \mathrm{b} .(1-c)$, in the spatiotemporal context of its occurrences (Table 5), it was admitted: the qualification being positive or negative; causality being direct or indirect; the local, regional and strategic geographical scope; long-term, mediumterm and immediate shortages; its duration, temporary or permanent; periodicity, being cyclical, intermittent and constant and reversibility.

Table 5: Matrix of the importance and relevance of impacts $\mathrm{Rg}=$ d.b.(1-c) during the implementation phase of USINA VERDE. Legend: NF - do not do the enterprise; S/PA - perform without environmental plan; C/PA - execute with environmental plans; Dir - direct causality; Ind - indirect causality; Loc - local coverage; Reg - regional coverage; Est strategic scope; IM - immediate lack; MP - medium term lack period; LP - long-term lacke period; Per - permanent duration; Tem - temporary duration; Cic - cyclical periodicity; Int - intermittent periodicity; Cte - constant periodicity; Rev - reversible reversibility; Irrev - irreversible reversibility.

\begin{tabular}{|c|c|c|c|c|c|c|c|c|c|c|c|c|c|c|c|c|}
\hline \multirow{2}{*}{ Impacts } & \multirow{2}{*}{ Alternatives } & \multicolumn{2}{|c|}{ Causality } & \multicolumn{3}{|c|}{ Coverage } & \multicolumn{3}{|c|}{ Lack } & \multicolumn{2}{|c|}{ Duration } & \multicolumn{3}{|c|}{ Periodicity } & \multicolumn{2}{|c|}{ Reversebility } \\
\hline & & Dir & Ind & Loc & Reg & Est & IM & MP & LP & Per & Tem & Cic & Int & Cte & Rev & Irrev \\
\hline \multirow{3}{*}{ Noise pollution } & $\mathrm{NF}$ & & 0.4 & 0.2 & & & 1 & & & 1 & & & & 0.7 & & 0.8 \\
\hline & S/PA & 0.6 & & 0.3 & & & 0.8 & & & & 0.4 & & 0.6 & & & 0.7 \\
\hline & $C / P A$ & 0.5 & & 0.2 & & & 0.7 & & & & 0.3 & 0.3 & & & & 0.5 \\
\hline \multirow{3}{*}{ Atmospheric pollution } & NF & & 0.3 & & & 0.5 & 1 & & & 1 & & & & 0.7 & & 0.8 \\
\hline & S / PA & 0.6 & & 0.3 & & & 0.9 & & & & 0.4 & & 0.6 & & & 0.7 \\
\hline & $C / P A$ & 0.5 & & 0.1 & & & 0.7 & & & & 0.3 & 0.3 & & & & 0.5 \\
\hline
\end{tabular}




\begin{tabular}{|c|c|c|c|c|c|c|c|c|c|c|c|c|c|c|c|}
\hline \multirow{3}{*}{ Temporary job creation } & NF & & 0 & & 0 & & & 0 & & 0 & & & 0 & & 0 \\
\hline & S / PA & 0.5 & & 0.1 & & 0.7 & & & & 0.2 & & 0.5 & & & 0.5 \\
\hline & $C / P A$ & 0.8 & & 0.3 & & 0.9 & & & & 0.4 & & 0.6 & & & 0.5 \\
\hline \multirow{3}{*}{ Neighborhood effect } & $\mathrm{NF}$ & & 0.4 & 0.3 & & & & 1 & 1 & & & & 1 & & 0.7 \\
\hline & S/PA & & 0.7 & 0.1 & & & & 1 & 1 & & & & 0.8 & & 0.6 \\
\hline & $\mathrm{C} / \mathrm{PA}$ & & 0.5 & 0.3 & & & 0 & & 0.5 & & 0.3 & & & & 0.5 \\
\hline \multirow{3}{*}{$\begin{array}{l}\text { Disturbance and loss of } \\
\text { biodiversity in the } \\
\text { surrounding ecosystems }\end{array}$} & $\mathrm{NF}$ & & 0.4 & & 0.4 & & & 1 & 1 & & & & 0.9 & & 0.8 \\
\hline & S/PA & & 0.7 & 0.3 & & & & 1 & 1 & & & 0.6 & & & 0.7 \\
\hline & $\mathrm{C} / \mathrm{PA}$ & & 0.5 & 0.1 & & & 0 & & 0.5 & & & 0.4 & & & 0.5 \\
\hline \multirow{3}{*}{$\begin{array}{l}\text { Interference in traffic and } \\
\text { daily life of social groups }\end{array}$} & NF & & 0.4 & 0.3 & & & & 1 & 1 & & & 0.6 & & & 0.7 \\
\hline & S/PA & 0.7 & & 0.3 & & & & 0.9 & 1 & & & 0.6 & & & 0.6 \\
\hline & $\mathrm{C} / \mathrm{PA}$ & 0.5 & & 0.1 & & 0.3 & & & 0.5 & & & 0.4 & & 0.4 & \\
\hline
\end{tabular}

Through the modeling of the variables the set of expressions made it possible to access that during the implementation phase of the enterprise were identified, 4 negative environmental impacts, 1 negative social impact and 1 positive social impact are identified (Table 6).

Table 6: Data modeling of the USINA VERDE project during the implementation phase of the project. Legend: NF - do not do the enterprise; S/PA - execute without environmental plans; C/PA - execute with environmental plans.

\begin{tabular}{|c|c|c|c|c|c|c|c|c|c|c|c|c|}
\hline \multirow{3}{*}{ Impacts } & \multirow{3}{*}{ Alternatives } & \multicolumn{11}{|c|}{ Algorithm } \\
\hline & & \multicolumn{5}{|c|}{$R g=d . b .(1-c)$} & \multicolumn{3}{|c|}{$\mathrm{Vpi}=\mathrm{QAE}_{\mathrm{TW}}-\mathbf{Q} \mathrm{A}_{\mathrm{TW}}$} & \multicolumn{3}{|c|}{ lad $=$ Rg.Vpi } \\
\hline & & Qualification & d & b & c & Rg & QAETW & QATW & Vpi & Rg & Vpi & lad \\
\hline \multirow{3}{*}{ Noise pollution } & NF & \multirow{3}{*}{-} & 0.3 & 0.9 & 0.8 & 0.05 & & 0.5 & 0.5 & 0.054 & 0.5 & 0.027 \\
\hline & $\mathrm{S} / \mathrm{PA}$ & & 0.45 & 0.6 & 0.7 & 0.08 & 0.3 & 0.5 & 0.2 & 0.081 & 0.2 & 0.0162 \\
\hline & $\mathrm{C} / \mathrm{PA}$ & & 0.35 & 0.43 & 0.5 & 0.08 & 0.4 & 0.5 & 0.1 & 0.075 & 0.1 & 0.0075 \\
\hline \multirow{3}{*}{ Atmospheric pollution } & $\mathrm{NF}$ & \multirow{3}{*}{-} & 0.4 & 0.9 & 0.8 & 0.07 & & 0.6 & 0.6 & 0.072 & 0.6 & 0.0432 \\
\hline & $\mathrm{S} / \mathrm{PA}$ & & 0.45 & 0.63 & 0.7 & 0.09 & 0.3 & 0.6 & 0.3 & 0.085 & 0.3 & 0.0255 \\
\hline & $\mathrm{C} / \mathrm{PA}$ & & 0.3 & 0.43 & 0.5 & 0.06 & 0.5 & 0.6 & 0.1 & 0.064 & 0.1 & 0.0064 \\
\hline \multirow{3}{*}{ Temporary job creation } & NF & \multirow{3}{*}{+} & 0 & 0 & 0 & 0 & & 0.4 & 0.4 & 0 & 0.4 & 0 \\
\hline & $\mathrm{S} / \mathrm{PA}$ & & 0.3 & 0.47 & 0.5 & 0.07 & 0.2 & 0.4 & 0.2 & 0.07 & 0.2 & 0.014 \\
\hline & $\mathrm{C} / \mathrm{PA}$ & & 0.55 & 0.63 & 0.5 & 0.17 & 0.3 & 0.4 & 0.1 & 0.173 & 0.1 & 0.0173 \\
\hline \multirow{3}{*}{ Neighborhood effect } & NF & \multirow{3}{*}{-} & 0.35 & 1 & 0.7 & 0.11 & & 0.8 & 0.8 & 0.105 & 0.8 & 0.084 \\
\hline & S/PA & & 0.4 & 0.93 & 0.6 & 0.15 & 0.3 & 0.8 & 0.5 & 0.148 & 0.5 & 0.074 \\
\hline & $\mathrm{C} / \mathrm{PA}$ & & 0.4 & 0.4 & 0.5 & 0.08 & 0.6 & 0.8 & 0.2 & 0.08 & 0.2 & 0.016 \\
\hline \multirow{3}{*}{$\begin{array}{l}\text { Disturbance and loss of } \\
\text { biodiversity in the } \\
\text { surrounding ecosystems }\end{array}$} & NF & \multirow{3}{*}{-} & 0.4 & 0.97 & 0.8 & 0.08 & & 0.6 & 0.6 & 0.077 & 0.6 & 0.0462 \\
\hline & $S / P A$ & & 0.5 & 0.87 & 0.7 & 0.13 & 0.4 & 0.6 & 0.2 & 0.13 & 0.2 & 0.026 \\
\hline & $C / P A$ & & 0.3 & 0.43 & 0.5 & 0.06 & 0.5 & 0.6 & 0.1 & 0.064 & 0.1 & 0.0064 \\
\hline \multirow{3}{*}{$\begin{array}{l}\text { Interference in traffic and } \\
\text { daily life of social groups }\end{array}$} & $\mathrm{NF}$ & \multirow{3}{*}{-} & 0.35 & 0.87 & 0.7 & 0.09 & & 0.6 & 0.6 & 0.091 & 0.6 & 0.0546 \\
\hline & $\mathrm{S} / \mathrm{PA}$ & & 0.5 & 0.83 & 0.6 & 0.17 & 0.3 & 0.6 & 0.3 & 0.166 & 0.3 & 0.0498 \\
\hline & $C / P A$ & & 0.3 & 0.4 & 0.4 & 0.07 & 0.4 & 0.6 & 0.2 & 0.072 & 0.2 & 0.0144 \\
\hline
\end{tabular}

Based on the summation of the impact expression (lad) is credible that the project is feasible as long as it is synthesized with environmental plans (Table 7). 
Table 7: Summation $(\Sigma)$ of the expression of impact (lad) during the implementation phase of USINA VERDE. Legend: NF - do not do the enterprise; S / PA - execute without environmental plans; C / PA - execute with environmental plans.

\begin{tabular}{|c|c|c|c|}
\hline lad & NF & S / PA & C /PA \\
\hline$\Sigma$ lad (+) & 0 & 0.014 & 0.0173 \\
\hline$\Sigma$ lad (-) & 0.255 & 0.1915 & 0.0507 \\
\hline
\end{tabular}

\section{Operation Phase of the Solid Waste Plant}

For the matrix of importance and relevance of impacts $(\mathrm{Rg})$ were modeled, 9 possible impacts were worked on for the operation phase, that is, two more impacts than the implementation phase of the USINA VERDE project (Table 8).

Table 8: Matrix of the importance and relevance of impacts $\mathrm{Rg}=\mathrm{d} . \mathrm{b}$. (1-c), during the operation phase of USINA VERDE. Legend: NF - do not do the enterprise; S/PA - perform without environmental plan; C/PA - execute with environmental plans; Dir - direct causality; Ind - indirect causality; Loc - local coverage; Reg - regional coverage; Est - strategic scope; IM - immediate lack; MP - medium term lack period; LP - long-term lacke period; Per - permanent duration; Tem temporary duration; Cic - cyclical periodicity; Int - intermittent periodicity; Cte - constant periodicity; Rev - reversible reversibility; Irrev - irreversible reversibility.

\begin{tabular}{|c|c|c|c|c|c|c|c|c|c|c|c|c|c|c|c|c|}
\hline \multirow{2}{*}{ Impacts } & \multirow{2}{*}{ Alternatives } & \multicolumn{2}{|c|}{ Causality } & \multicolumn{3}{|c|}{ coverage } & \multicolumn{3}{|c|}{ Lack } & \multicolumn{2}{|c|}{ Duration } & \multicolumn{3}{|c|}{ Periodicity } & \multicolumn{2}{|c|}{ Reversebility } \\
\hline & & Dir & Ind & Loc & Reg & Est & IM & MP & LP & Per & Tem & Cic & Int & Cte & $\operatorname{Rev}$ & Irrev \\
\hline \multirow{3}{*}{ Noise pollution } & NF & & 0.4 & 0.2 & & & & & 0.3 & 0.8 & & & & 0.7 & & 0.5 \\
\hline & S / PA & 0.7 & & 0.3 & & & 0.8 & & & 0.5 & & & 0.6 & & 0.4 & \\
\hline & $C / P A$ & 0.5 & & 0.2 & & & 0.7 & & & & 0.4 & 0.3 & & & 0.1 & \\
\hline \multirow{3}{*}{ Generation of odors } & NF & & 0.4 & & 0.4 & & & 0.6 & & 0.8 & & & 0.6 & & & 0.5 \\
\hline & S / PA & 0.7 & & 0.3 & & & & 0.5 & & 0.5 & & 0.3 & & & 0.4 & \\
\hline & $C / P A$ & 0.5 & & 0.1 & & & & 0.4 & & & 0.3 & 0.1 & & & 0.1 & \\
\hline \multirow{3}{*}{$\begin{array}{l}\text { Reduction of vector } \\
\text { proliferation }\end{array}$} & NF & & 0 & & & 0 & & & 0 & & 0 & & & 0 & & 0 \\
\hline & S/PA & 0.9 & & & 0.4 & & & 0.5 & & 0.7 & & & & 0.7 & & 0.7 \\
\hline & $C / P A$ & 1 & & & 0.6 & & 0.7 & & & 0.9 & & & & 0.9 & & 0.8 \\
\hline \multirow{3}{*}{$\begin{array}{l}\text { Reduction in the } \\
\text { level of } \\
\text { contamination of soil } \\
\text { and aquifers }\end{array}$} & NF & & 0 & & & 0 & & & 0 & & 0 & & & 0 & & 0 \\
\hline & S / PA & 0.8 & & & 0.4 & & & 0.6 & & 0.5 & & & & 0.7 & & 0.7 \\
\hline & $\mathrm{C} / \mathrm{PA}$ & 1 & & & 0.6 & & 0.7 & & & 0.9 & & & & 0.9 & & 0.9 \\
\hline \multirow{3}{*}{$\begin{array}{c}\text { Increase in vehicle } \\
\text { traffic }\end{array}$} & NF & & 0.4 & & 0.6 & & & & 0.7 & 0.6 & & & & 0.7 & & 0.6 \\
\hline & $\mathrm{S} / \mathrm{PA}$ & 0.7 & & 0.3 & & & & 0.5 & & 0.5 & & & 0.6 & & 0.4 & \\
\hline & $C / P A$ & 0.5 & & 0.1 & & & 0.3 & & & 0.4 & & 0.3 & & & 0.3 & \\
\hline \multirow{3}{*}{ Jobs Generation } & NF & & 0.2 & 0.2 & & & & & 0.3 & & 0.4 & 0.3 & & & 0.1 & \\
\hline & $\mathrm{S} / \mathrm{PA}$ & 0.5 & & 0.2 & & & 0.7 & & & 0.5 & & & 0.4 & & & 0.6 \\
\hline & $C / P A$ & 0.7 & & 0.3 & & & 0.9 & & & 0.8 & & & 0.5 & & & 0.8 \\
\hline \multirow{3}{*}{$\begin{array}{l}\text { Waste recycling and } \\
\text { mineralization }\end{array}$} & NF & & 0.3 & 0.1 & & & & & 0.3 & & 0.3 & 0.3 & & & 0.1 & \\
\hline & S/PA & 0.6 & & 0.3 & & & 0.7 & & & 0.5 & & & & 0.7 & & 0.8 \\
\hline & $\mathrm{C} / \mathrm{PA}$ & 0.8 & & & 0.6 & & 0.9 & & & 0.8 & & & & 0.9 & & 0.9 \\
\hline \multirow{3}{*}{$\begin{array}{l}\text { Temporary } \\
\text { impediment to the } \\
\text { operation of the } \\
\text { mineralization plant }\end{array}$} & $\mathrm{NF}$ & & 0 & & & 0 & & & 0 & & 0 & & & 0 & & 0 \\
\hline & S/PA & 0.6 & & 0.2 & & & & & 0.3 & & 0.3 & 0.1 & & & 0.2 & \\
\hline & $C / P A$ & 0.5 & & 0.1 & & & & & 0.3 & & 0.3 & 0.1 & & & 0.1 & \\
\hline \multirow{3}{*}{$\begin{array}{c}\text { Alteration of Air } \\
\text { Quality }\end{array}$} & $\mathrm{NF}$ & 1 & & 0.3 & & & & & 1 & & 1 & & & 1 & & 0.8 \\
\hline & S/PA & 0.6 & & 0.2 & & & & 0.7 & & & 0.5 & 0.3 & & & 0.4 & \\
\hline & $\mathrm{C} / \mathrm{PA}$ & & 0.3 & 0.1 & & & 0.3 & & & 0.3 & & 0.1 & & & 0.2 & \\
\hline
\end{tabular}


Through the modeling of the variables, the set of expressions made it possible to access that during the phase of operation of the enterprise, 4 negative environmental impacts, 3 positive environmental impacts, 1 negative social impact and 1 positive social impact are identified (Table 9).

Environmental impacts and positive social impacts during the operation phase are beneficial to society and the environment being possible actors of profound changes in the regional and local environmental framework.

Table 9: Data modeling of the USINA VERDE project during the operation phase of the project. Legend: NF - do not do the enterprise; S/PA - execute without environmental plans; C/PA - execute with environmental plans.

\begin{tabular}{|c|c|c|c|c|c|c|c|c|c|c|c|c|}
\hline \multirow{3}{*}{ Impacts } & \multirow{3}{*}{ Alternatives } & \multicolumn{11}{|c|}{ Algorithm } \\
\hline & & \multicolumn{5}{|c|}{$R g=d . b .(1-c)$} & \multicolumn{3}{|c|}{ 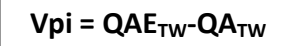 } & \multicolumn{3}{|c|}{ lad $=$ Rg.Vpi } \\
\hline & & Qualification & d & b & c & Rg & QAETW & QATW & Vpi & $\mathbf{R g}$ & Vpi & lad \\
\hline \multirow{3}{*}{ Noise pollution } & $\mathrm{NF}$ & \multirow{3}{*}{ - } & 0.3 & 0.6 & 0.5 & 0.09 & & 0.6 & 0.6 & 0.09 & 0.6 & 0.054 \\
\hline & S / PA & & 0.5 & 0.63 & 0.4 & 0.189 & 0.4 & 0.6 & 0.2 & 0.189 & 0.2 & 0.0378 \\
\hline & $C / P A$ & & 0.35 & 0.47 & 0.1 & 0.148 & 0.5 & 0.6 & 0.1 & 0.148 & 0.1 & 0.0148 \\
\hline \multirow{3}{*}{$\begin{array}{l}\text { Generation of } \\
\text { odors }\end{array}$} & NF & \multirow{3}{*}{ - } & 0.4 & 0.67 & 0.5 & 0.134 & & 0.4 & 0.4 & 0.134 & 0.4 & 0.0536 \\
\hline & S / PA & & 0.5 & 0.43 & 0.4 & 0.129 & 0.2 & 0.4 & 0.2 & 0.129 & 0.2 & 0.0258 \\
\hline & $C / P A$ & & 0.3 & 0.27 & 0.1 & 0.072 & 0.3 & 0.4 & 0.1 & 0.072 & 0.1 & 0.0072 \\
\hline \multirow{3}{*}{$\begin{array}{l}\text { Reduction of vector } \\
\text { proliferation }\end{array}$} & NF & \multirow{3}{*}{+} & 0 & 0 & 0 & 0 & & 0.5 & 0.5 & 0 & 0.5 & 0 \\
\hline & S / PA & & 0.65 & 0.63 & 0.7 & 0.123 & 0.2 & 0.5 & 0.3 & 0.123 & 0.3 & 0.0369 \\
\hline & $C / P A$ & & 0.8 & 0.83 & 0.7 & 0.199 & 0.3 & 0.5 & 0.2 & 0.199 & 0.1 & 0.0398 \\
\hline \multirow{3}{*}{$\begin{array}{l}\text { Reduction in the } \\
\text { level of } \\
\text { contamination of } \\
\text { soil and aquifers }\end{array}$} & NF & \multirow{3}{*}{+} & 0 & 0 & 0 & 0 & & 0.7 & 0.7 & 0 & 0.7 & 0 \\
\hline & S / PA & & 0.6 & 0.6 & 0.7 & 0.108 & 0.4 & 0.7 & 0.3 & 0.108 & 0.3 & 0.0324 \\
\hline & $C / P A$ & & 0.8 & 0.83 & 0.7 & 0.199 & 0.5 & 0.7 & 0.2 & 0.199 & 0.1 & 0.0398 \\
\hline \multirow{3}{*}{$\begin{array}{c}\text { Increase in vehicle } \\
\text { traffic }\end{array}$} & NF & \multirow{3}{*}{ - } & 0.5 & 0.67 & 0.6 & 0.134 & & 0.5 & 0.5 & 0.134 & 0.5 & 0.067 \\
\hline & S / PA & & 0.5 & 0.53 & 0.4 & 0.159 & 0.3 & 0.5 & 0.2 & 0.159 & 0.2 & 0.0318 \\
\hline & $C / P A$ & & 0.3 & 0.33 & 0.3 & 0.069 & 0.4 & 0.5 & 0.1 & 0.069 & 0.1 & 0.0069 \\
\hline \multirow{3}{*}{ Jobs Generation } & NF & \multirow{3}{*}{+} & 0.2 & 0.33 & 0.1 & 0.059 & & 0.3 & 0.3 & 0.059 & 0.3 & 0.0177 \\
\hline & $\mathrm{S} / \mathrm{PA}$ & & 0.35 & 0.53 & 0.6 & 0.074 & 0.1 & 0.3 & 0.2 & 0.074 & 0.2 & 0.0148 \\
\hline & $C / P A$ & & 0.5 & 0.73 & 0.6 & 0.146 & 0.2 & 0.3 & 0.1 & 0.146 & 0.1 & 0.0146 \\
\hline \multirow{3}{*}{$\begin{array}{l}\text { Waste recycling } \\
\text { and mineralization }\end{array}$} & NF & \multirow{3}{*}{+} & 0.2 & 0.3 & 0.1 & 0.054 & & 0.6 & 0.6 & 0.054 & 0.6 & 0.0324 \\
\hline & $\mathrm{S} / \mathrm{PA}$ & & 0.45 & 0.63 & 0.8 & 0.057 & 0.4 & 0.6 & 0.2 & 0.057 & 0.2 & 0.0114 \\
\hline & $C / P A$ & & 0.7 & 0.87 & 0.8 & 0.122 & 0.5 & 0.6 & 0.1 & 0.122 & 0.1 & 0.0122 \\
\hline \multirow{3}{*}{$\begin{array}{c}\text { Temporary } \\
\text { impediment to the } \\
\text { operation of the } \\
\text { mineralization } \\
\text { plant }\end{array}$} & NF & \multirow{3}{*}{ - } & 0 & 0 & 0 & 0 & & 0.3 & 0.3 & 0 & 0.3 & 0 \\
\hline & S / PA & & 0.4 & 0.23 & 0.2 & 0.074 & 0.1 & 0.3 & 0.2 & 0.074 & 0.2 & 0.0148 \\
\hline & $C / P A$ & & 0.3 & 0.23 & 0.1 & 0.062 & 0.2 & 0.3 & 0.1 & 0.062 & 0.1 & 0.0062 \\
\hline \multirow{3}{*}{$\begin{array}{l}\text { Alteration of Air } \\
\text { Quality }\end{array}$} & $N F$ & \multirow{3}{*}{-} & 0.65 & 1 & 0.8 & 0.13 & & 0.5 & 0.5 & 0.13 & 0.5 & 0.065 \\
\hline & S/PA & & 0.4 & 0.5 & 0.4 & 0.12 & 0.3 & 0.5 & 0.2 & 0.12 & 0.2 & 0.024 \\
\hline & $C / P A$ & & 0.2 & 0.23 & 0.2 & 0.037 & 0.4 & 0.5 & 0.1 & 0.037 & 0.1 & 0.0037 \\
\hline
\end{tabular}

Based on the summation of the impact expression (lad) it is credible that the project is feasible as long as it is synthesized with environmental plans (Table 10). As was also evaluated during the 
implementation phase of the project.

Table 10: Summation ( $\Sigma$ ) of the expression of impact (lad) during the operation phase of USINA VERDE. Legend: NF - do not do the enterprise; S PA - execute without environmental plans; C / PA - execute with environmental plans.

\begin{tabular}{|c|c|c|c|}
\hline lad & NF & S / PA & C /PA \\
\hline$\Sigma \operatorname{lad}(+)$ & 0.0501 & 0.0955 & 0.1064 \\
\hline$\Sigma \operatorname{lad}(-)$ & 0.2396 & 0.1342 & 0.0388 \\
\hline
\end{tabular}

\section{CONCLUSIONS}

This article clearly demonstrates that the proposed methodology lends itself in an adequate way to serve as a tool in the analysis of environmental impacts. In the present case, USINA VERDE had as a result of the presented methodology the conclusion that the project is viable from an environmental point of view as long as the implementation of environmental plans is admitted.

ACKNOWLEDGMENT: To Helium Corp for funding and scientific contribution. To the Brazilian Scientific Production Company (CBPC) for rereading, organizing and publishing this work.

\section{REFERENCES}

ALMEIDA, J. R.; LINS, G. A.; AQUINO, A. R.; EGUTE, N. S.. Avaliação Integrada de Impactos Ambientais de Usinas Termoelétricas (UTG). Revista Brasileira de Pesquisa e Desenvolvimento, v.10, p.145-157, 2008.

ALMEIDA, J. R.; CASTRO, S. M.; RODRIGUES, M. G.. Valoração de Dados Ambientais da Geração Termelétrica: Usina de Campos dos Goytacazes/RJ. Revista Internacional de Ciências, v.2, p.67-78, 2012

ALMEIDA, J. R.; AGUIAR, L. A.; RODRIGUES, M. G.. Impactos Ambientais de Usinas Termoelétricas à gás:estudo de caso da UTG Duque de Caxias. In: América Latina y el proceso de modernización, 2005, Roma. Anais da Federación Internacional de estufios sobre América Latina y el Caribe. Roma: FIEALC, v.2, p.47-54, 2005.

BOND, A. J.; POPE, J.; MORRISON-SAUNDERS, A.; RETIEF, F.; GUNN, J. A. E.. Impact assessment: Eroding benefits through streamlining? Environmental Impact Assessment Review, v.45, p.46-53, 2014.

CONAMA. Conselho Nacional do Meio Ambiente. Ministério do Meio Ambiente. Resolução CONAMA n. 01, de 23 de janeiro de 1986. Dispõe sobre critérios básicos e diretrizes gerais para a avaliação de impacto ambiental. Brasília: CONAMA, 1986.

GIBSON, R. B.. In full retreat: the Canadian government's new environmental assessment law undoes decades of progress. Impact Assessment and Project Appraisal, v.30, n.3, p.179-188, 2012.

IBGE. Instituto Brasileiro de Geografia e Estatística. Censo de 2019. Rio de Janeiro: IBGE, 2019.

MARQUES, E. D.; TUBBS FILHO, D.; SILVA FILHO, E. V.. Influência das variações do nível freático na química da água subterrânea, Aqüífero Piranema? Bacia de Sepetiba, R. Geochimica Brasiliensis, v.22, n.3, p.213-228, 2008. DOI: http://dx.doi.org/10.21715/gb.v22i3.290

MORGAN, R. K.. Environmental impact assessment: the state of the art. Impact Assessment and Project Appraisal, v.30, n.1, p.5-14, 2012.

SILVA, C. V. V.; MAGALHÃES C.. Risco Ambiental da Construção do CTR Santa Rosa Sobre o Aquífero Piranema. In: JORNADA DE INICIAÇÃO CIENTÍFICA DA UFRRJ, 21. Anais. Seropédica, 2011.

SILVA, J. M.; SANTOS, M. O. S.; AUGUSTO, L. G. S.; GURGEL, I. G. D.. Desenvolvimento sustentável e saúde do trabalhador nos estudos de impacto ambiental de refinarias no Brasil. Saúde e Sociedade, v.22, n.3, p.687-700, 2013.

TORO, J.; REQUENA, I.; ZAMORANO, M.. Environmental impact assessment in Colombia: Critical analysis and proposals for improvement. Environmental Impact Assessment Review, v.30, n.4, p.247-261, 2010.

A CBPC - Companhia Brasileira de Produção Científica (CNPJ: 11.221.422/0001-03) detém os direitos materiais desta publicação. Os direitos referem-se à publicação do trabalho em qualquer parte do mundo, incluindo os direitos às renovações, expansões e disseminações da contribuição, bem como outros direitos subsidiários. Todos os trabalhos publicados eletronicamente poderão posteriormente ser publicados em coletâneas impressas sob coordenação da Sustenere Publishing, da Companhia Brasileira de Produção Científica e seus parceiros autorizados. Os (as) autores (as) preservam os direitos autorais, mas não têm permissão para a publicação da contribuição em outro meio, impresso ou digital, em português ou em tradução. 